\title{
Application of Titanium-Silica-Graphite Composite Material for Photocatalytic Process of Methylene Blue
}

\section{Lia Destiarti* and Risya Sasri}

Department of Chemistry, Universitas Tanjungpura, Jl. Prof. Dr. Hadari Nawawi, Pontianak 78114, West Kalimantan, Indonesia

\section{* Corresponding author:}

tel: $+62-81345208035$

email:lia.destiarti@chemistry.untan.ac.id

Received: August 25, 2019

Accepted: April 29, 2020

DOI: $10.22146 / \mathrm{ijc} .48998$

\begin{abstract}
The use of $\mathrm{TiO}_{2}$ in the slurry system for the photocatalytic process has disadvantages. It causes the resistance of UV transmission because it is cloudy and the difficulty for obtaining the catalyst at the end of the process. Therefore, an attempt to overcome this was conducted by compositing $\mathrm{TiO}_{2}$ on $\mathrm{SiO}_{2}$. Furthermore, carbon material can be used as a support material for $\mathrm{TiO}_{2}-\mathrm{SiO}_{2}$, so that the mixed materials can be used as a photocatalyst. The method of synthesis of the material was a sol-gel method by varying the composition of $\mathrm{TiO}_{2}-\mathrm{SiO}_{2} /$ graphite, which was 1:1; 1:2; and 2:1. The material obtained was characterized by FTIR, DRUV, XRD, and SEM. Photocatalytic activity of the synthesized material was tested in methylene blue solution, whereas the quantitative data derived from UV-Vis spectrometry measurement. Photocatalyst activity was carried out by varying the degradation time of 30-180 min. The FTIR spectrum showed that $\mathrm{O}-\mathrm{H}\left(\sim 3400 \mathrm{~cm}^{-1}\right)$ and $\mathrm{C}-\mathrm{O}\left(\sim 1100 \mathrm{~cm}^{-1}\right)$ are the major groups in the synthesized materials. The value of bandgap energy $\left(E_{g}\right)$ were $4.15,4.20$, 5.22, and $5.19 \mathrm{eV}$ for $\mathrm{TiO}_{2}-\mathrm{SiO}_{2}, \mathrm{TiO}_{2}-\mathrm{SiO}_{2} / \mathrm{G}(1: 1 ; 1: 2$; and 2:1) composites, respectively. The XRD pattern of $\mathrm{TiO}_{2}-\mathrm{SiO}_{2}$ showed that the highest peaks of $2 \theta$ were observed at $25.32,37.71$, and $47.91^{\circ}$. Graphite identity appeared at $2 \theta=59.87^{\circ}$. The micrograph of SEM showed a homogenous dispersion of spherical particles in the materials. Photocatalytic test results showed that $\mathrm{TiO}_{2}-\mathrm{SiO}_{2} / \mathrm{G}$ with a composition of 2:1 has the highest percentage of methylene blue degradation, which reached $94 \%$ at $180 \mathrm{~min}$.
\end{abstract}

Keywords: titanium dioxide; silica; graphite; photocatalytic; methylene blue

\section{- INTRODUCTION}

Methylene blue is a chemical used in the textile and painting industry. Industrial dye and textile dye are one of the largest groups of toxic organic compounds [1]. Methylene blue becomes the primary source of environmental contamination. The degradation and conversion of them into harmless substances is an important issue [2]. Physical and chemical methods are used to solve this problem. However, the complexity of the organic compound becomes a severe problem. The conventional method only transfers the pollution from a phase to another phase and concentrate them, and also are non-destructive processes. In recent years, the Advanced Oxidation Process (AOPs) techniques become more popular than conventional methods. An example of AOPs is photocatalytic using titanium dioxide $\left(\mathrm{TiO}_{2}\right)$ as a catalyst.

Titanium dioxide is widely known as a photocatalyst in the photocatalytic method. This method has the advantage of being able to degrade organic matter with complex structures. However, the use of $\mathrm{TiO}_{2}$ in the photocatalytic process has a disadvantage. The turbidity generated in aqueous solution by $\mathrm{TiO}_{2}$ dispersion will inhibit UV light transmission as an activator of $\mathrm{TiO}_{2}$ catalysts. Also, $\mathrm{TiO}_{2}$ in the form of slurry will make difficulties in separating $\mathrm{TiO}_{2}$ at the end of the photocatalytic process [3-5].

A photocatalytic reaction occurs when $\mathrm{TiO}_{2}$ photocatalyst is irradiated with energy equal or greater than the bandgap energy, the electron moves to the conduction band to generate positive holes in the 
valence band. The positive holes can react with adsorbed $\mathrm{H}_{2} \mathrm{O}$ to form hydroxyl radicals while the electrons react with $\mathrm{O}_{2}$ to form superoxide radicals. The $\mathrm{OH}$ and $\mathrm{O}_{2}$ radicals can oxidize the pollutants in solution with adsorbed contaminants. Otherwise, these electron and hole pairs can recombine and restrict the efficiency of $\mathrm{TiO}_{2}$ photocatalyst [6]. Thus, much effort has been made to overcome this problem. One of them is to combine $\mathrm{TiO}_{2}$ into other materials.

Titania-carbon nanotubes composite was used to degrade organic pollutants in aqueous solutions. This composite can increase UV radiation adsorption compared to pure $\mathrm{TiO}_{2}$. Doping $\mathrm{TiO}_{2}$ with nonmetal elements has received much attention, especially for carbon element, whereas the $\mathrm{C}$ element did not enter the $\mathrm{TiO}_{2}$ lattice but deposited on the surface of $\mathrm{TiO}_{2}$ grains [7]. Another example of photocatalyst material is graphite/ $\mathrm{PbTiO}_{3}$ composite that can be used for photocatalysis and photoelectrocatalysis of organic matter [8]. The combination of $\mathrm{TiO}_{2}$ with carbonaceous nanomaterials can increase photocatalytic activity [9]. Carbon nanotubes are used as $\mathrm{TiO}_{2}$ supports, and it can increase electron-hole recombination time as electron catchers [10]. Besides that, $\mathrm{rGO}-\mathrm{ZnO}-\mathrm{Fe}_{3} \mathrm{O}_{4}$ nanocomposite was made using the solvothermal method and tested its photocatalytic activity on rhodamine B samples [11]. The results of this study indicate that the dye could be degraded to $90 \%$, and the nanocomposite was quickly recovered with magnetic fields. This recovery method can occur because of the presence of $\mathrm{Fe}_{3} \mathrm{O}_{4}$ in the synthesis material. Magnetic photocatalysts containing $\mathrm{TiO}_{2}$ nanocrystals have been synthesized, and the result is that the catalyst can be separated easily from the wastes. Photocatalytic activity of $\mathrm{Fe}_{3} \mathrm{O}_{4} / \mathrm{TiO}_{2}$-Co has been tested to degrade methylene blue, and the catalyst can be separated magnetically [5].

Titanium dioxide can also be applied to carbon-based materials. Photocatalysis using $\mathrm{TiO}_{2}$-biochar (biomass charcoal) can be used to degrade sulfamethoxazole [12]. Biochar is used as a cheap and efficient $\mathrm{TiO}_{2}$ support to reduce the electron-hole recombination rate during the photocatalysis process, efficient insertion of $\mathrm{TiO}_{2}$, to increase adsorption capacity, and to make the separation of photocatalysts from samples after use can be conducted efficiently. Granule activated carbon plays a useful role in the process of photocatalysis of carbofuran [13]. The results of this study indicate that $100 \%$ of carbofuran can be degraded.

The structure and chemical composition of $\mathrm{TiO}_{2}-$ $\mathrm{SiO}_{2}$ nanopowder composites changed the photocatalyst activity [14]. The silica doped in the titania matrix can increase the photocatalytic activity because the silica doping decreases particle size and also increase the specific area. The catalytic activity of $\mathrm{TiO}_{2}-\mathrm{SiO}_{2}$ is better than $\mathrm{TiO}_{2}$ and $\mathrm{SiO}_{2}[3,15]$. The structure of the synthesis material can change with the calcination process. Also, the composition of $\mathrm{SiO}_{2}$ in $\mathrm{TiO}_{2}-\mathrm{SiO}_{2}$ composites determines its photocatalyst activity. The $\mathrm{TiO}_{2} / \mathrm{SiO}_{2}$ functionalized carbon nanotubes are among the most promising photocatalytic candidates for the degradation of emerging pollutants [16].

In this study, the synthesis of $\mathrm{TiO}_{2}, \mathrm{TiO}_{2}-\mathrm{SiO}_{2}$, and $\mathrm{TiO}_{2}-\mathrm{SiO}_{2} / \mathrm{G}$ composites will be carried out using the sol-gel method. The composite materials obtained were analyzed using FTIR, DRUV, SEM, and XRD. The materials were then tested on the industrial waste model, methylene blue dye, to determine the photocatalytic activity (time variation). The profile of methylene blue reduction is done by observing the UV-Vis spectrum profile.

\section{- EXPERIMENTAL SECTION}

\section{Materials}

Titanium tetraisopropoxide (TTIP) and tetraethylorthosilicate (TEOS) were obtained from Aldrich. Sodium hydroxide $(\mathrm{NaOH})$, nitric acid $\left(\mathrm{HNO}_{3}\right)$, ammonium hydroxide $\left(\mathrm{NH}_{4} \mathrm{OH}\right)$, ethanol $\left(\mathrm{C}_{2} \mathrm{H}_{6} \mathrm{O}\right)$, and methylene blue were acquired from Merck. Hydrochloric acid $(\mathrm{HCl})$ was derived from Mallinckrodt. Used dry battery cells was taken for graphite source, and DI water was used to make all solution.

\section{Instrumentation}

In this research, the instrumentations used were a photocatalytic reactor and UV-Vis Spectrophotometer (Shimadzu 1280). Instrumentations used for 
characterization of composites were FTIR Prestige 21 (Shimadzu), X-Ray Diffraction (XRD X'PERT POWDER PW 30/40), and Diffuse Reflectance Ultra Violet Spectrophotometer (Shimadzu DR UV 2450), Scanning Electron Microscope-SEM Hitachi SU3500, using Au coating.

\section{Procedure}

\section{Preparation of graphite}

Carbon powder was taken from used dry battery cells. The powder was ground and soaked in $250 \mathrm{~mL}$ of $0.1 \mathrm{M}$ nitric acid solution for $24 \mathrm{~h}$. The suspension was separated into filtrate and residue. The residue was washed with distilled water and dried at $80{ }^{\circ} \mathrm{C}$ for $3 \mathrm{~h}$. Carbon powder was sifted; the carbon used was the particle with size $\leq 100$ mesh.

\section{Preparation of $\mathrm{TiO}_{2}-\mathrm{SiO}_{2}$}

Five milliliters of TEOS was mixed to ethanol by 1:6 comparison. TEOS was added to ethanol dropwise. Then, $\mathrm{HCl} 0.05 \mathrm{M}$ was added drop-by-drops to the solution until the $\mathrm{pH}$ of the mixture solution was 2 , continued by stirring for $2 \mathrm{~h}$. The product from this step was called $\mathrm{SiO}_{2}$ solution.

Titanium tetraisopropoxide was dissolved in DI water by comparison (1:14). The solution was stirred until homogeneous for $2 \mathrm{~h}$, and $\mathrm{SiO}_{2}$ solution was poured to $75 \mathrm{~mL}$ TTIP solution. It was stirred for $24 \mathrm{~h}$. An amount of $0.05 \mathrm{M} \mathrm{NH}_{4} \mathrm{OH}$ was added to adjust the $\mathrm{pH}$ solution. The solution of Ti-Si was stirred until homogeneous and heated at $65^{\circ} \mathrm{C}$ for $\pm 1 \mathrm{~h}$ to obtain sol-gel. For the aging process, the sol-gel was heated at $100^{\circ} \mathrm{C}$ for $2 \mathrm{~h}$.

\section{Preparation of $\mathrm{TiO}_{2}-\mathrm{SiO}_{2} / \mathrm{G}$ composite}

The method is a modification of Purnawan et al. [8]. First step: $5 \mathrm{~mL}$ of TEOS was added dropwise into $30 \mathrm{~mL}$ ethanol while the solution was stirred continuously. It was added by $2 \mathrm{~mL}$ of $0.05 \mathrm{M} \mathrm{HCl}$ slowly to the system until the $\mathrm{pH}$ of the solution was two and stirred for $2 \mathrm{~h}$. Second step: $5 \mathrm{~mL}$ TTIP was dissolved in $70 \mathrm{~mL}$ of DI water. It was continued by mixing process until homogeneous, and then added by the solution derived from the first step, and stirred for $24 \mathrm{~h}$. An amount of $0.05 \mathrm{M} \mathrm{NH}_{4} \mathrm{OH}$ was added to adjust the $\mathrm{pH}$ then stirred until homogeneous. The graphite powder was combined with variations of 1:2, 1:1, and $2: 1 \% \mathrm{w} / \mathrm{w}\left(\mathrm{TiO}_{2}-\mathrm{SiO}_{2} / \mathrm{G}\right)$. The suspension was heated at $65{ }^{\circ} \mathrm{C}$ for $1 \mathrm{~h}$. The sol form was heated at $150{ }^{\circ} \mathrm{C}$ for $2 \mathrm{~h}$ to have an aging process. The sol-gel of $\mathrm{TiO}_{2}-\mathrm{SiO}_{2} / \mathrm{G}$ was calcinated at $400{ }^{\circ} \mathrm{C}$ for $2 \mathrm{~h}$, to produce $\mathrm{TiO}_{2}-\mathrm{SiO}_{2} / \mathrm{G}$ composite.

\section{Photocatalytic of methylene blue}

The photocatalytic activity of the $\mathrm{TiO}_{2}-\mathrm{SiO}_{2}, \mathrm{TiO}_{2}-$ $\mathrm{SiO}_{2} / \mathrm{G}=1: 1, \mathrm{TiO}_{2}-\mathrm{SiO}_{2} / \mathrm{G}=1: 2, \mathrm{TiO}_{2}-\mathrm{SiO}_{2} / \mathrm{G}=2: 1$, and graphite was evaluated by observing the degradation process of methylene blue (MB) solution, as a model of industrial waste. The initial concentration of $\mathrm{MB}$ was $14 \mathrm{mg} / \mathrm{L}$, and the sample solution volume was $200 \mathrm{~mL}$. The mass of the loading catalyst was $1 \mathrm{~g} / \mathrm{L}$. The reactor was irradiated with a $6 \times 10 \mathrm{~W}$ UV black light lamp. The starting point $(t=0)$ of the reaction was defined as the point where the concentration of the sample solution was recorded as $\mathrm{C}_{0}$. Afterward, $3 \mathrm{~mL}$ of each mixture was taken at regular intervals of 30,60,90,120,120, and $105 \mathrm{~min}$. The powders were separated using a 0.45 membrane filter. The dye concentration in the solution (filtrate) was measured as a function of the irradiation time. The measurement was conducted using a UV-Vis spectrophotometer. The spectral range was investigated at $\lambda=665 \mathrm{~nm}$. The degradation capacity $(\eta \%)$ was calculated as $\eta(\%)=(1-\mathrm{C} / \mathrm{Co}) \times 100 \%[5,8,17]$.

\section{- RESULTS AND DISCUSSION}

The sol-gel and hydrothermal method have been considered as an alternative for $\mathrm{Si}$-Ti preparation due to no requirement of high temperature. The precursor of $\mathrm{Ti}$ and $\mathrm{Si}$ were derived from TTIP and TEOS, respectively. The hydrolysis starts when the precursor reacts with water and follows by the condensation process that changes the solution to become the sol. After solvent vaporization, the gel will be formed, and after the drying process, the silica-titania mixture is obtained.

The criteria of adsorbents in integrated photocatalyst system are high adsorption capacity yet moderate affinity to the target compound and reasonable transparency to UV-Vis light. Other requirements of the materials are high surface area with acceptable pore size, acting as support material which 
inhibits leaching of photocatalyst, and good stability with solvent and reusability [18]. Graphite is chosen in this research as the adsorbent.

\section{FTIR Analysis}

FTIR spectroscopy was used to characterize the interaction between graphite, titania, and silica. Fig. 1 shows the FTIR spectra of the graphite and titanium dioxide. The dominant peaks that are commonly present in graphitic material such as 1008,1579 , and $2922 \mathrm{~cm}^{-1}$ correspond to the stretching of $\mathrm{C}-\mathrm{O}$, asymmetric stretching vibration of $\mathrm{C}=\mathrm{C}$, and stretching of $\mathrm{C}-\mathrm{H}$. This data is supported by Basheer [6]. The broad peak related to the vibration of the hydroxyl $(-\mathrm{OH})$ group also can be seen at a wavenumber of $3425 \mathrm{~cm}^{-1}$. The IR spectra of $\mathrm{TiO}_{2}$ show a broad and strong band at 3408 and $1631 \mathrm{~cm}^{-1}$ that can be identified as $-\mathrm{OH}$ groups from the adsorbed water on the surface of titania indicating stretching and bending vibration, respectively.

Fig. 2 shows the comparison of the IR spectrum between $\mathrm{TiO}_{2}-\mathrm{SiO}_{2} / \mathrm{G}$ in various compositions. The pattern of $\mathrm{TiO}_{2}-\mathrm{SiO}_{2} / \mathrm{G}$ and $\mathrm{TiO}_{2}-\mathrm{SiO}_{2}$ is quite similar. The peak observed at $\sim 1100 \mathrm{~cm}^{-1}$ corresponds to $\mathrm{Si}-\mathrm{O}-\mathrm{Si}$ asymmetric stretching vibration. The Si-O-Ti vibrates at $\sim 960 \mathrm{~cm}^{-1}$. The more the graphite added into the mixture of titania-silica, the lower the intensity of the $\mathrm{OH}$ band became. The data was supported by Riazian, [14], and Yaseen et al. [15]. Further characterization is needed to determine the effect of graphite addition to the $\mathrm{TiO}_{2}-\mathrm{SiO}_{2}$ composites.

\section{DRUV Analysis}

Fig. 3 shows the DRUV spectra of synthesized materials. This characterization was conducted to measure the band gap energy of materials. The value of band gap energy $\left(\mathrm{E}_{\mathrm{g}}\right)$ was determined using the Tauc plot of the Kubelka Munk equation. The $\mathrm{E}_{\mathrm{g}}$ of materials were $4.15,4.20,5.22$, and 5.19 for $\mathrm{TiO}_{2}-\mathrm{SiO}_{2}, \mathrm{TiO}_{2}$ $\mathrm{SiO}_{2} / \mathrm{G}=1: 1, \mathrm{TiO}_{2}-\mathrm{SiO}_{2} / \mathrm{G}=1: 2$, and $\mathrm{TiO}_{2}-\mathrm{SiO}_{2} / \mathrm{G}=2: 1$, respectively. Based on this data, the lowest band gap energy is $\mathrm{TiO}_{2}-\mathrm{SiO}_{2}$. The addition of graphite to $\mathrm{TiO}_{2}-$ $\mathrm{SiO}_{2}$ can increase the number of band gap energy. The more the number of graphite added to the Ti-Si makes the $\mathrm{E}_{\mathrm{g}}$ becomes higher than the others.

\section{XRD Characterization}

There are three crystalline forms of $\mathrm{TiO}_{2}$ which are anatase, brookite, and rutile. The anatase phase is reported

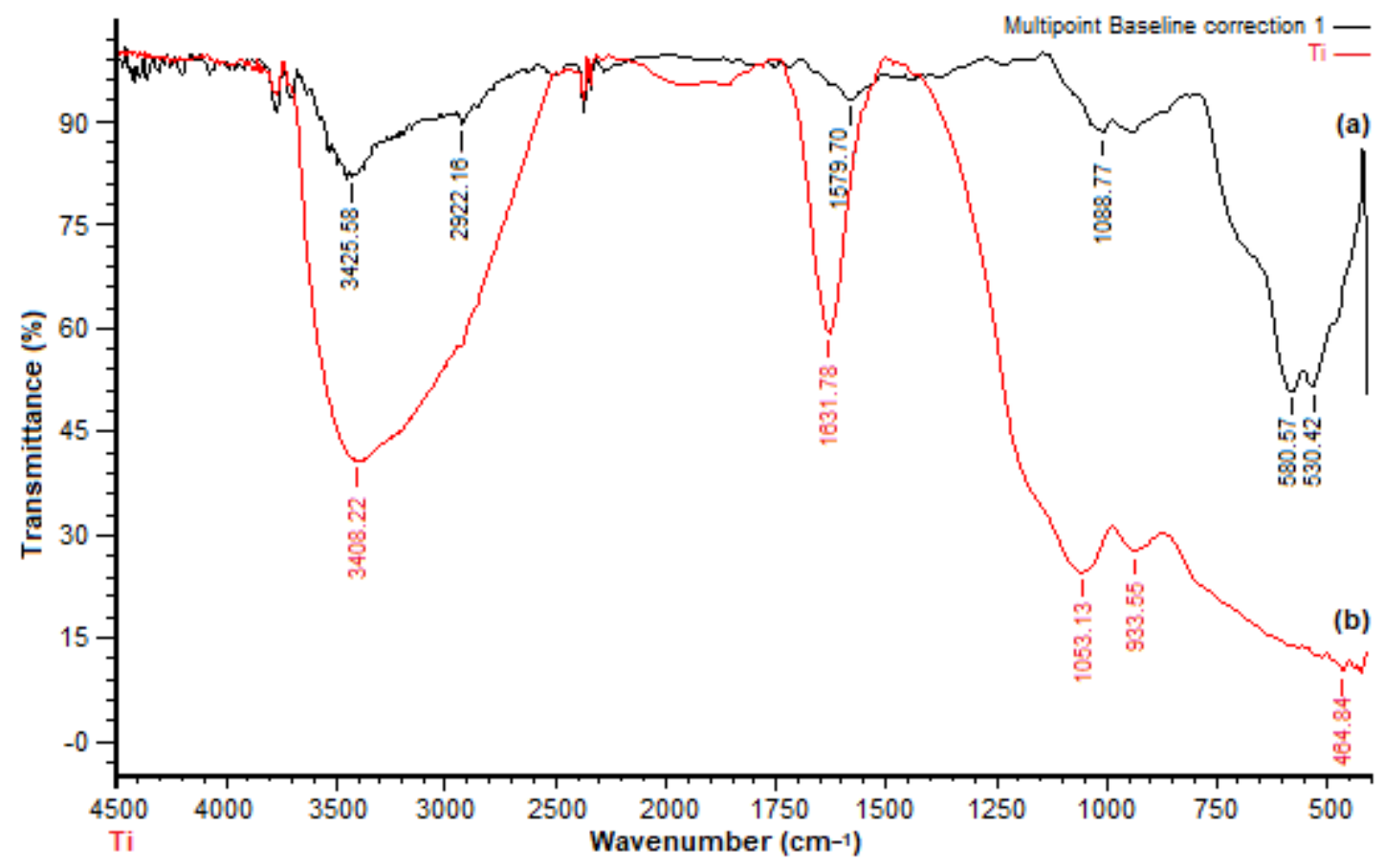

Fig 1. FTIR spectrum of graphite (a) and titanium dioxide (b) 


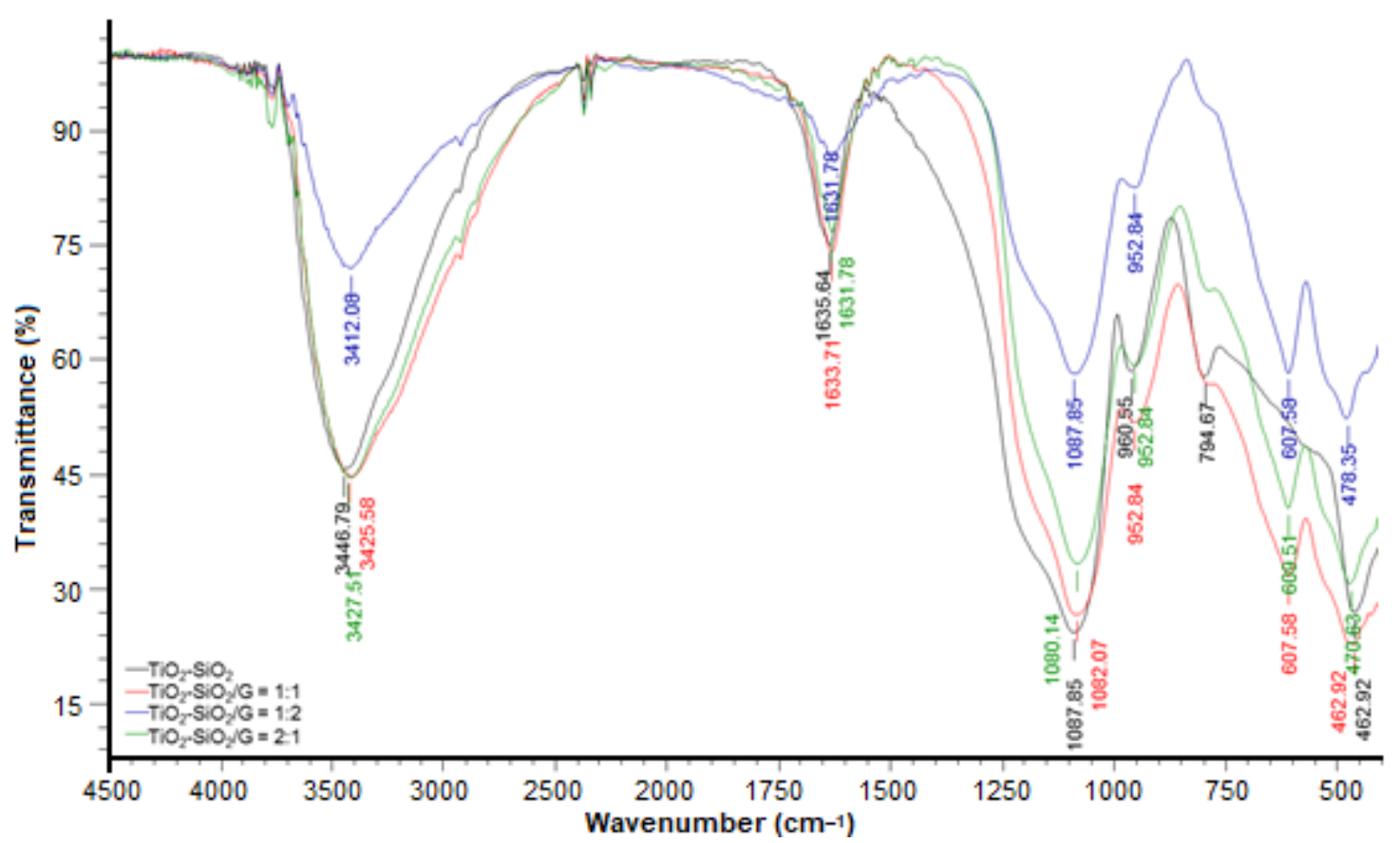

Fig 2. FTIR spectrum of synthesized materials

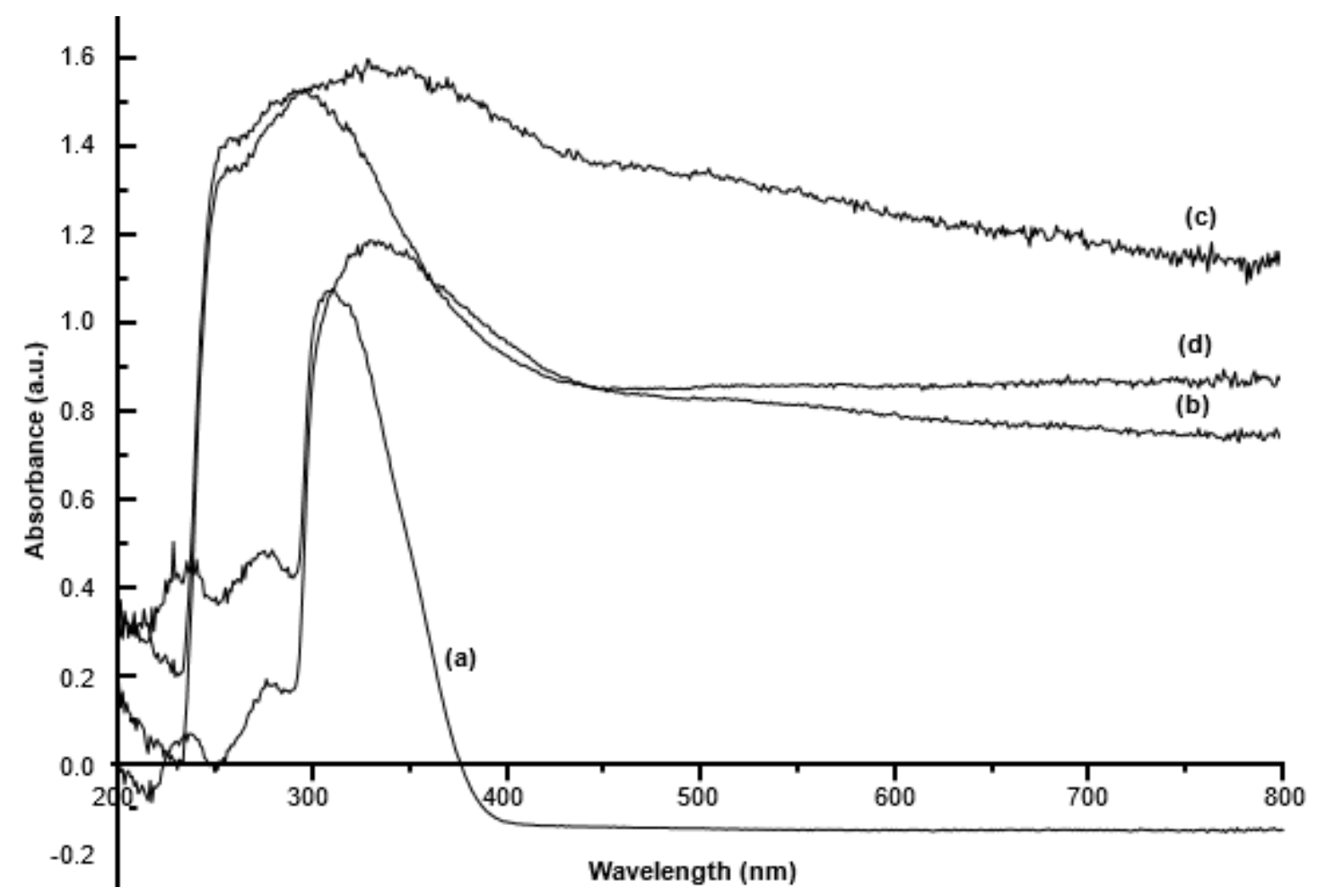

Fig 3. DR-UV Visible spectra of $\mathrm{TiO}_{2}-\mathrm{SiO}_{2}(\mathrm{a}), \mathrm{TiO}_{2}-\mathrm{SiO}_{2} / \mathrm{G}=1: 1$ (b), $\mathrm{TiO}_{2}-\mathrm{SiO}_{2} / \mathrm{G}=1: 2$ (c), and $\mathrm{TiO}_{2}-\mathrm{SiO}_{2} / \mathrm{G}=2: 1$ (d)

to give the best combination of photoactivity and photostability. The $\mathrm{TiO}_{2}-\mathrm{SiO}_{2}$ has the highest peak at $2 \theta=$ $25.32 ; 37.71$ and $47.91^{\circ}$. The data reported was compared to the $\mathrm{TiO}_{2}$ standard (JCPDS No. 01-075-2546) and $\mathrm{SiO}_{2}$ standard (JCPDS No. 01-070-2535). It can be seen that the $\mathrm{TiO}_{2}-\mathrm{SiO}_{2}$ diffraction pattern follows the dominant characteristics of $\mathrm{TiO}_{2}$, while the amorphous $\mathrm{SiO}_{2}$ influences the intensity of the composite diffraction 
pattern. The composite characteristics of $\mathrm{TiO}_{2}-\mathrm{SiO}_{2}$ also show a similar pattern with $\mathrm{TiO}_{2}$ crystals, which can be seen in Table 1. The identity of $\mathrm{SiO}_{2}$ appeals at $2 \theta$ of 53.70 and $62.54^{\circ}$, which corresponds to (022) and (113) planes, respectively.

Fig. 4 shows the XRD pattern of $\mathrm{TiO}_{2}-\mathrm{SiO}_{2}$ and three formula of $\mathrm{TiO}_{2}-\mathrm{SiO}_{2} / \mathrm{G}$. The diffractogram shows the presence of graphite, $\mathrm{TiO}_{2}$, and $\mathrm{SiO}_{2}$ in the sample. A characteristic angle shift occurs for $\mathrm{TiO}_{2}-\mathrm{SiO}_{2}$ after interaction with graphite. However, the diffraction pattern of $\mathrm{TiO}_{2}$ appears at $2 \theta$ of 25.32 and $37.71^{\circ}$, which corresponds to (101) and (004) planes. The $\mathrm{SiO}_{2}-\mathrm{G}$ characteristic was confirmed at $2 \theta=59.87^{\circ}$, which was concluded by comparison with the standard graphite

Table 1. $\mathrm{d}$ Spacing of $\mathrm{TiO}_{2}$ and $\mathrm{TiO}_{2}-\mathrm{SiO}_{2}$ lattices

\begin{tabular}{lllcccc}
\hline Samples & $\mathrm{h}$ & $\mathrm{k}$ & $\mathrm{L}$ & $2 \theta(\mathrm{deg})$ & $\mathrm{d}_{\text {hkl }}(\AA)$ & Assigned Peak of \\
\hline $\mathrm{TiO}_{2}$ & 1 & 0 & 1 & 25.47 & 3.49 & $\mathrm{NA}$ \\
& 0 & 0 & 4 & 37.75 & 2.38 & $\mathrm{NA}$ \\
& 2 & 0 & 0 & 47.96 & 1.89 & $\mathrm{NA}$ \\
$\mathrm{TiO}_{2}-\mathrm{SiO}_{2}$ & 1 & 0 & 1 & 25.32 & 3.51 & $\mathrm{TiO}_{2}$ \\
& 0 & 0 & 4 & 37.71 & 2.38 & $\mathrm{TiO}_{2}$ \\
& 2 & 0 & 0 & 47.91 & 1.89 & $\mathrm{TiO}_{2}$ \\
& 0 & 2 & 2 & 53.70 & 1.71 & $\mathrm{SiO}_{2}$ \\
& 1 & 1 & 3 & 62.54 & 1.48 & $\mathrm{SiO}_{2}$ \\
\hline
\end{tabular}

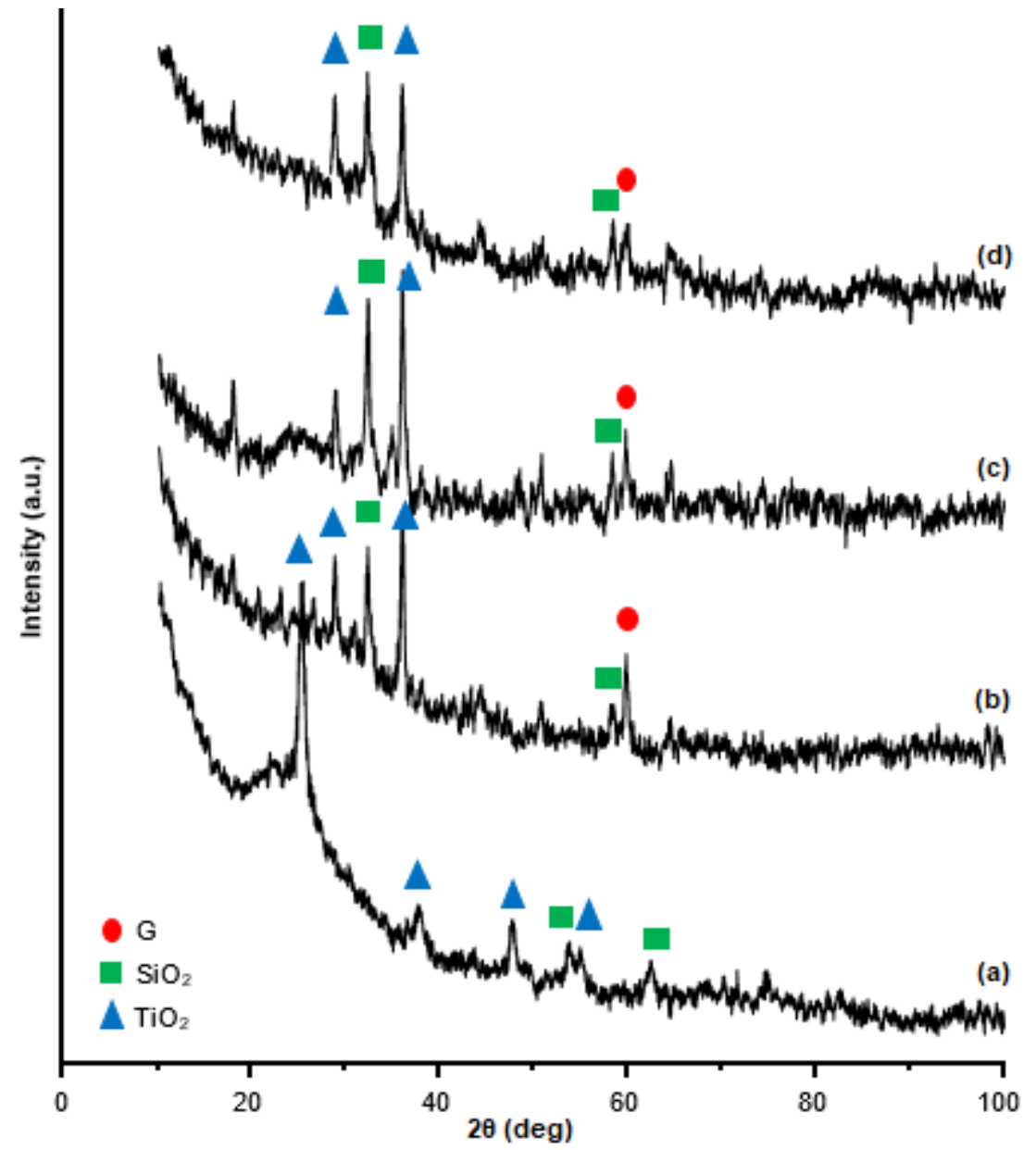

Fig 4. Diffractogram of $\mathrm{TiO}_{2}-\mathrm{SiO}_{2}$ (a), $\mathrm{TiO}_{2}-\mathrm{SiO}_{2} / \mathrm{G}=1: 1$ (b), $\mathrm{TiO}_{2}-\mathrm{SiO}_{2} / \mathrm{G}=1: 2$ (c), and $\mathrm{TiO}_{2}-\mathrm{SiO}_{2} / \mathrm{G}=2: 1$ (d) 
Table 2. Comparison of $2 \theta$ and $\mathrm{d}_{\mathrm{hkl}}$ of synthesized materials

\begin{tabular}{lcccccc}
\hline Samples & $\mathrm{h}$ & $\mathrm{K}$ & $\mathrm{L}$ & $2 \theta(\mathrm{deg})$ & $\mathrm{d}_{\text {hkl }}(\AA)$ & Assigned Peak of \\
\hline $\mathrm{TiO}_{2}-\mathrm{SiO}_{2}$ & 1 & 0 & 1 & 25.32 & 3.51 & $\mathrm{TiO}_{2}(\mathrm{~A})$ \\
& 0 & 0 & 4 & 37.71 & 2.38 & $\mathrm{TiO}_{2}(\mathrm{~A})$ \\
& 2 & 0 & 0 & 47.91 & 1.89 & $\mathrm{TiO}_{2}$ \\
& 0 & 2 & 2 & 53.70 & 1.71 & $\mathrm{SiO}_{2}$ \\
& 1 & 1 & 3 & 62.54 & 1.48 & $\mathrm{SiO}_{2}$ \\
\hline $\mathrm{TiO}_{2}-\mathrm{SiO}_{2} / \mathrm{G}=1: 1$ & 1 & 1 & 0 & 28.85 & 3.09 & $\mathrm{TiO}_{2}(\mathrm{R})$ \\
& 1 & 1 & 0 & 32.33 & 2.77 & $\mathrm{SiO}_{2}$ \\
& 0 & 0 & 4 & 36.04 & 2.49 & $\mathrm{TiO}_{2}(\mathrm{~A})$ \\
& 1 & 2 & 1 & 58.54 & 1.58 & $\mathrm{SiO}_{2}$ \\
& 1 & 0 & 3 & 59.87 & 1.54 & $\mathrm{G}$ \\
\hline $\mathrm{TiO}_{2}-\mathrm{SiO}_{2} / \mathrm{G}=1: 2$ & 1 & 1 & 0 & 28.84 & 3.09 & $\mathrm{TiO}_{2}(\mathrm{R})$ \\
& 1 & 1 & 0 & 32.34 & 2.77 & $\mathrm{SiO}_{2}$ \\
& 0 & 0 & 4 & 36.03 & 2.49 & $\mathrm{TiO}_{2}(\mathrm{~A})$ \\
& 1 & 0 & 3 & 59.90 & 1.54 & $\mathrm{G}$ \\
\hline $\mathrm{TiO}_{2}-\mathrm{SiO}_{2} / \mathrm{G}=2: 1$ & 1 & 1 & 0 & 28.87 & 3.09 & $\mathrm{TiO}_{2}(\mathrm{R})$ \\
& 1 & 1 & 0 & 32.33 & 2.77 & $\mathrm{SiO}_{2}$ \\
& 0 & 0 & 4 & 36.02 & 2.49 & $\mathrm{TiO}_{2}(\mathrm{~A})$ \\
& 1 & 2 & 1 & 58.47 & 1.58 & $\mathrm{SiO}_{2}$ \\
& 1 & 0 & 3 & 59.80 & 1.54 & $\mathrm{G}$ \\
\hline
\end{tabular}

diffractogram (JCPDS No 03-065-6212). Interestingly, when graphite was added to $\mathrm{TiO}_{2}-\mathrm{SiO}_{2}$, the characteristic of the two diffraction angles for $\mathrm{TiO}_{2}$ shifted from $2 \theta=$ $25.32^{\circ}$ to $\sim 28.85^{\circ}$ and $2 \theta=37.71^{\circ}$ to $\sim 36.04^{\circ}$ after the composite was formed. This phenomenon reveals that there was a change of $\mathrm{TiO}_{2}$ form; anatase becomes rutile. Some publications stated that dopant could be a reason for anatase to rutile transition, size, and strain of materials as the factors [19-20]. This result is supported by Rahmawati et al., the character of 2 theta of $\mathrm{SiO}_{2}$ $\mathrm{TiO}_{2} /$ Graphite is labeled as rutile rises in $37.53^{\circ}$ [21]. The transformation in its publication is due to the use of high temperature in the calcination process. Anatase and rutile phases are easier to differentiate since the first two reflection peaks are well separated. The 2 theta of anatase is $25.28^{\circ}$ for $d_{101}$ while the rutile gives $27.44^{\circ}$ for $d_{110}$ [22]. This research indicates that graphite tends to change the phase of $\mathrm{TiO}_{2}$ in $\mathrm{TiO}_{2}-\mathrm{SiO}_{2}$ but not entirely, so the $\mathrm{TiO}_{2}$ becomes a mixture of rutile-anatase.

The identity of graphite shows that the $d_{103}$ peak presents at $59.8^{\circ}$ with a value of $1.54 \AA$. To look deep that the character of $\mathrm{Si}$ in $\mathrm{TiO}_{2}-\mathrm{SiO}_{2}$ is 53.7 , and $62.54^{\circ}$ become
32.33 and $58.54^{\circ}$ in $\mathrm{TiO}_{2}-\mathrm{SiO}_{2} / \mathrm{G}$. The peak at value $\mathrm{d}_{121}$ of $58.80^{\circ}$ disappears when the formula with more graphite than the $\mathrm{TiO}_{2}-\mathrm{SiO}_{2}\left(\mathrm{TiO}_{2}-\mathrm{SiO}_{2} / \mathrm{G}=1: 2\right)$. This phenomenon proves that the composite has a different phase composition when the formula is changed.

\section{SEM Analysis}

The SEM images of $\mathrm{TiO}_{2}-\mathrm{SiO}_{2}, \mathrm{TiO}_{2}-\mathrm{SiO}_{2} / \mathrm{G}=1: 1$, $\mathrm{TiO}_{2}-\mathrm{SiO}_{2} / \mathrm{G}=1: 2$, and $\mathrm{TiO}_{2}-\mathrm{SiO}_{2}=2: 1$ are shown in Fig. $5(\mathrm{a}-\mathrm{d})$. As can be seen in Fig. 5, there is an increasing roughness throughout the surface of the $\mathrm{TiO}_{2}-\mathrm{SiO}_{2} / \mathrm{G}$ with the increase of loaded $\mathrm{TiO}_{2}-\mathrm{SiO}_{2}$. The aggregates on the images indicate the existence of interaction of the titanium dioxide layers on the particle surface (graphite). The uniform of a homogenous dispersion of spherical particles is the outcome of synthesis that takes place during the condensation stage [23]. This data supports the XRD analysis that Ti-O-Si was formed. This structure can provide significant surface area contact between $\mathrm{TiO}_{2}-\mathrm{SiO}_{2}$ and graphite particles, and also have a good potential for carrier transport, related to the photocatalytic activity. 

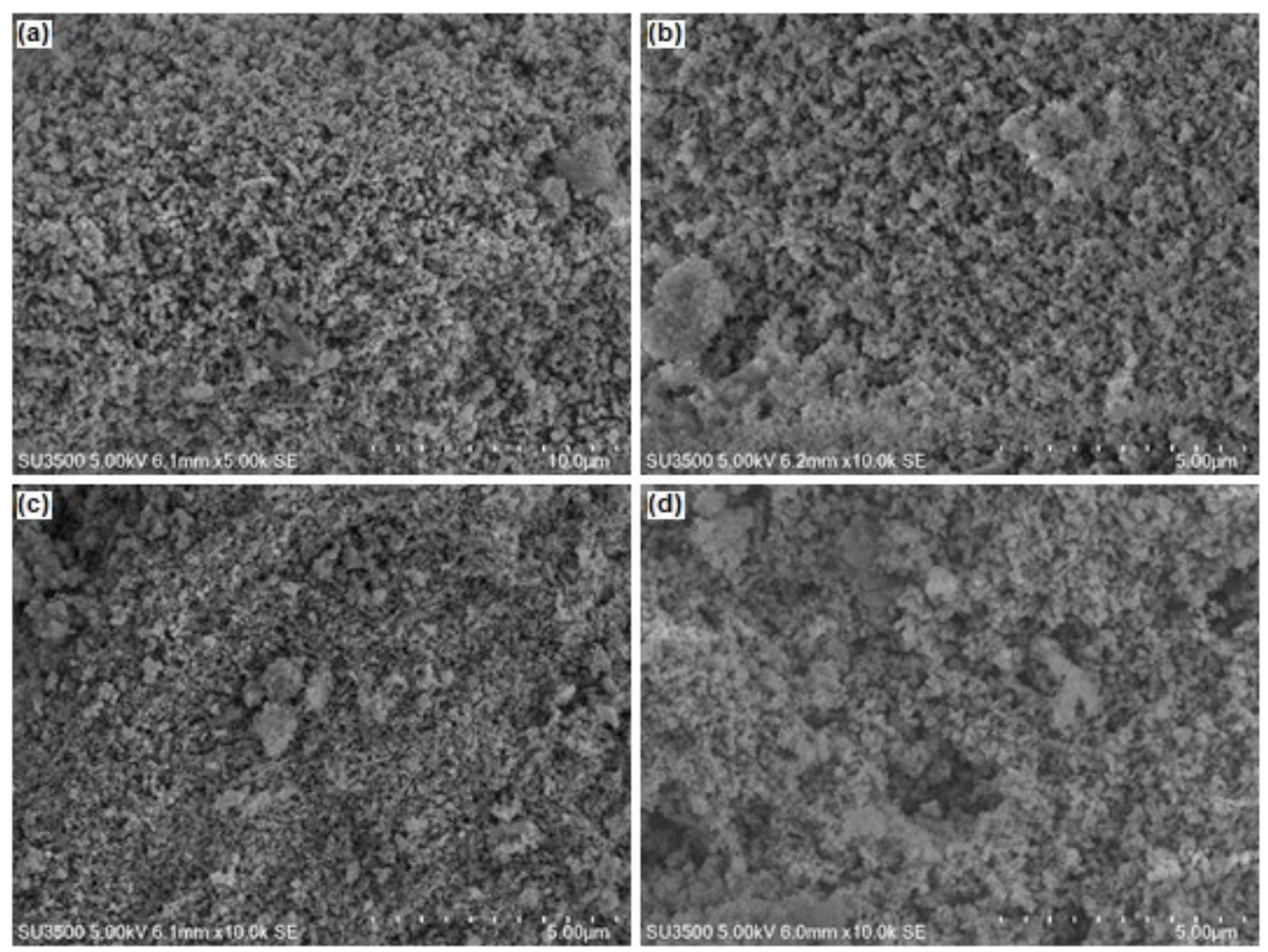

Fig 5. Micrograph $\mathrm{SEM}$ of $\mathrm{TiO}_{2}-\mathrm{SiO}_{2}(\mathrm{a}), \mathrm{TiO}_{2}-\mathrm{SiO}_{2} / \mathrm{G}=1: 1$ (b), $\mathrm{TiO}_{2}-\mathrm{SiO}_{2} / \mathrm{G}=1: 2$ (c), and $\mathrm{TiO}_{2}-\mathrm{SiO}_{2} / \mathrm{G}=2: 1$ (d)

\section{Photocatalytic Activity}

The $\mathrm{TiO}_{2}$ itself as the photocatalyst faces several problems, (1) the difficulty in separating the powder from the solution after the reaction is complete, (2) aggregation of particles in suspensions, and (3) difficulty in an application for continues flows system [9]. The graphite can provide a high-surface-area structure over which $\mathrm{TiO}_{2}$ particles may be distributed and immobilized. The role of $\mathrm{SiO}_{2}$ is as electron trapper for the excited electron from the valence band of $\mathrm{TiO}_{2}$, and this mechanism can reduce the possibility of electron-hole recombination [21].

The combination of $\mathrm{TiO}_{2}-\mathrm{SiO}_{2}$ material already proved to give an increase in photocatalytic activity. The combination of $\mathrm{TiO}_{2}-\mathrm{SiO}_{2}$ as a catalyst in the photocatalytic process showed an excellent activity to degrade organic compound, phenol, and linear alkyl benzenesulfonate [3]. Also, graphite silica was used by Ikeda et al. to the photocatalytic process to produce hydrogen [24]. The GS successfully combined with $\mathrm{TiO}_{2}$, and as the results, the photocatalytic activity increases significantly.
The photocatalytic activities of graphite and $\mathrm{TiO}_{2}-$ $\mathrm{SiO}_{2} / \mathrm{G}$ composites were evaluated by degradation of a hazardous textile dye (methylene blue, MB). Absorbance spectra of $\mathrm{MB}$ aqueous solution were measured using a UV-Vis spectrophotometer at $500-750 \mathrm{~nm}$ are shown in Fig. 6. The spectra were taken after irradiation of $\mathrm{MB}$ solution for specific irradiation time $(0,30,60,90,120$, 150 , and $180 \mathrm{~min})$. Generally, it can be seen clearly that absorbance peaks at $665 \mathrm{~nm}$ decreased with increasing of irradiation time (Fig. 6(a-e).

The photocatalytic activities of all materials on the degradation process of $\mathrm{MB}$ were shown via the plot of degradation efficiency as a function of time (Fig. 6(f)). The data demonstrated that photocatalytic activity by applying the graphite itself has an efficiency value of $14 \%$, the lowest value than other composites. After using the $\mathrm{TiO}_{2}-\mathrm{SiO}_{2} / \mathrm{G}$ as the photocatalyst, the efficiency can increase sharply where the range of the value is $65-94 \%$. The photocatalytic ability by applying $\mathrm{TiO}_{2}-\mathrm{SiO}_{2}$ gave an efficiency value of $83 \%$, higher than $\mathrm{TiO}_{2}-\mathrm{SiO}_{2} / \mathrm{G}=1: 1$ (76\%) and $\mathrm{TiO}_{2}-\mathrm{SiO}_{2} / \mathrm{G}=1: 2(65 \%)$. By having more 

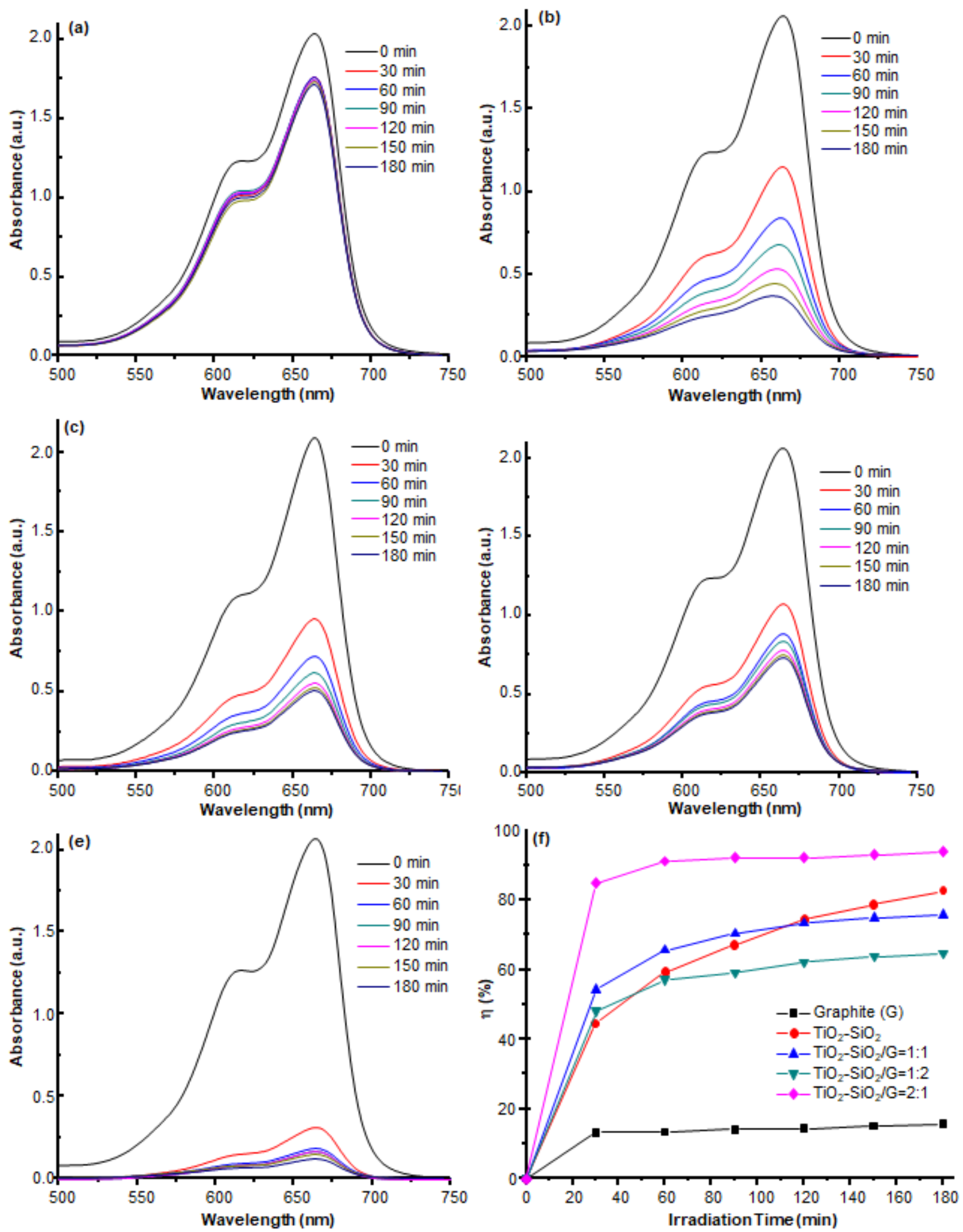

Fig 6. The degradation profile of $M B$ using synthesized materials (a-e) and the efficiency of degradation versus irradiation time using all synthesized materials $(\mathrm{f})$ 
graphite in $\mathrm{TiO}_{2}-\mathrm{SiO}_{2}$, the efficiency become lower. On the contrary, while $\mathrm{TiO}_{2}-\mathrm{SiO}_{2}$ had been added with $\mathrm{G}$ in a ratio formula of $2: 1$, the data give $11 \%$ increase from the activity of $\mathrm{TiO}_{2}-\mathrm{SiO}_{2}$, to be $94 \%$. It can be concluded that the role of graphite can increase the activity of $\mathrm{TiO}_{2}-\mathrm{SiO}_{2}$ in a particular formula. The result of this research has an agreement with Lang and Matejka [25] and Andriantsiferana et al. [26].

The existence of graphite in the $\mathrm{TiO}_{2}-\mathrm{SiO}_{2}$ composite may increase the rate of $\mathrm{MB}$ photodegradation. Guidetti et al. reported that graphite can decrease the charge recombination rate, and increases the efficiency of the reactive species photo-production, so that the photocatalytic activity can increase [27]. The photocatalytic of anatase is higher than rutile. This performance is attributed to a higher density of localized states and consequent surface-adsorbed hydroxyl radicals and slower charge recombination in anatase relative to rutile [20]. Even though, based on this data, the composition of $\mathrm{G}$ in $\mathrm{TiO}_{2}-\mathrm{SiO}_{2}$ composite role significant effect on photocatalytic power. The bandgap of $\mathrm{TiO}_{2}$ $\mathrm{SiO}_{2} / \mathrm{G}$ has a broad band gap, which is $4.1-5.2 \mathrm{eV}$ allows the adsorption of the photon to excite an electron from the conductance band to the valence band. When the excitation happens, electron-hole is generated. The electron reacts with an $\mathrm{O}_{2}$ molecule creating an unstable $\cdot \mathrm{O}_{2}^{-}$molecule. At the same time, the photogenerated holes $\left(\mathrm{h}^{+}\right)$with strong oxidation ability could react with $\mathrm{H}_{2} \mathrm{O}$ to produce radical hydroxyl $(\bullet \mathrm{OH})$. The generated species can degrade the $\mathrm{MB}$ and other organic complex dyes [28].

\section{- CONCLUSION}

The titanium-silica-graphite composites were successfully synthesized by the sol-gel method. The precursors are TTIP, TEOS, and graphite from the used battery. The character of the FTIR spectrum showed that $\mathrm{O}-\mathrm{H}\left(\sim 3400 \mathrm{~cm}^{-1}\right)$ and C-O $\left(\sim 1100 \mathrm{~cm}^{-1}\right)$ are the major groups in the synthesized materials. The value of band gap energy is increasing by the addition of graphite. The Diffractogram of XRD shows the identity of $\mathrm{Ti}, \mathrm{Si}$, and graphite. The micrograph of SEM showed the uniform of a homogenous dispersion of spherical particles in the materials. Photocatalytic test results with these synthesis materials as a catalyst to degrade methylene blue showed that $\mathrm{TiO}_{2}-\mathrm{SiO}_{2} / \mathrm{G}$ with a composition of $2: 1$ has the highest percentage of degradation, which reached $94 \%$ at $180 \mathrm{~min}$.

\section{- ACKNOWLEDGMENTS}

This research was funded by Mathematics and Natural Sciences Faculty, Universitas Tanjungpura Pontianak, under DIPA UNTAN Grant No. SP DIPA042.01.2.400955/2018. The authors express great gratitude for that support.

\section{- REFERENCES}

[1] Ajmal, A., Majeed, I., Malik, N., Idriss, H., and Nadeem, M.A., 2014, Principles and mechanisms of photocatalytic dye degradation on $\mathrm{TiO}_{2}$ based photocatalysts: A comparative overview, RSC Adv., 4 (70), 37003-37026.

[2] Dariani, R.S., Esmaeili, A., Mortezaali, A., and Dehghanpour, S., 2016, Photocatalytic reaction and degradation of methylene blue on $\mathrm{TiO}_{2}$ nano-sized particles, Optik, 127 (18), 7143-7154.

[3] Destiarti, L., Tjokronegoro, R., Rakhmawaty, D., and Rudiyansyah, R., 2015, The use of $\mathrm{TiO}_{2}-\mathrm{SiO}_{2}$ in photocatalytic process to degrade toxic and dangerous waste, Makara J. Sci., 19 (1), 1-6.

[4] Lin, J., Luo, Z., Liu, J., and Li, P., 2018, Photocatalytic degradation of methylene blue in aqueous solution by using $\mathrm{ZnO}-\mathrm{SnO}_{2}$ nanocomposites, Mater. Sci. Semicond. Process., 87, 24-31.

[5] Kunarti, E.S., Kartini, I., Syoufian, A., and Widyandari, K.M., 2018, Synthesis and photoactivity of $\mathrm{Fe}_{3} \mathrm{O}_{4} / \mathrm{TiO}_{2}$-Co as a magnetically separable visible light responsive photocatalyst, Indones. J. Chem., 18 (3), 403-410.

[6] Basheer, C., 2013, Application of titanium dioxidegraphene composite material for photocatalytic degradation of alkylphenols, J. Chem., 2013, 456586.

[7] Chen, L., Chen, F., Shi, Y., and Zhang, J., 2012, Preparation and visible light photocatalytic activity of a graphite-like carbonaceous surface modified $\mathrm{TiO}_{2}$ photocatalyst, J. Phys. Chem. C, 116 (15), 8579-8586. 
[8] Purnawan, C., Wahyuningsih, S., and Kusuma, P.P., 2016, Photocatalytic and photoelectrocatalytic degradation of methyl orange using graphite $/ \mathrm{PbTiO}_{3}$ composite, Indones. J. Chem., 16 (3), 347-352.

[9] Leary, R., and Westwood, A., 2010, Carbonaceous nanomaterials for the enhancement of $\mathrm{TiO}_{2}$ photocatalysis, Carbon, 49 (3), 741-772.

[10] Cao, Q., Yu, Q., Connell, D.W., and Yu, G., 2013, Titania/carbon nanotube composite $\left(\mathrm{TiO}_{2} / \mathrm{CNT}\right)$ and its application for removal of organic pollutants, Clean Technol. Environ. Policy, 15, 871-880.

[11] You, J., Xiang, Y., Ge, Y., He, Y., and Song, G., 2017, Synthesis of ternary $\mathrm{rGO}-\mathrm{ZnO}-\mathrm{Fe}_{3} \mathrm{O}_{4}$ nanocomposites and their application for visible light photocatalytic degradation of dyes, Clean Technol. Environ. Policy, 19 (8), 2161-2169.

[12] Kim, J.R., and Kan, E., 2016, Heterogeneous photocatalytic degradation of sulfamethoxazole in water using a biochar-supported $\mathrm{TiO}_{2}$ photocatalyst, J. Environ. Manage., 180, 94-101.

[13] Vishnuganth, M.A., Remya, N., Kumar, M., and Selvaraju, N., 2016, Photocatalytic degradation of carbofuran by $\mathrm{TiO}_{2}$-coated activated carbon: Model for kinetic, electrical energy per order and economic analysis, J. Environ. Manage., 181, 201-207.

[14] Riazian, M., 2014, Dependence of Photocatalytic activity of $\mathrm{TiO}_{2}-\mathrm{SiO}_{2}$ nanopowders, J. Nanostruct., 4, 433-441.

[15] Yaseen, M., Shah, Z., Veses, R.C., Dias, S.L.P., Lima, E.C., dos Reis, G.S., Vaghetti, J.C.P., Alencar, W.S.D., and Mahmood, K., 2017, Photocatalytic studies of $\mathrm{TiO}_{2}-\mathrm{SiO}_{2}$ nanocomposites xerogels, J. Anal. Bioanal. Tech., 8 (1), 348.

[16] Rasheed, T., Adeel, M., Nabeel, F., Bilal, M., and Iqbal, H.M.N., 2019, $\mathrm{TiO}_{2} / \mathrm{SiO}_{2}$ decorated carbon nanostructured materials as a multifunctional platform for emerging pollutants removal, Sci. Total Environ., 688, 299-311.

[17] Nguyen, D.C.T., Cho, K.Y., and Oh, W.C., 2017, Synthesis of mesoporous $\mathrm{SiO}_{2} / \mathrm{Cu}_{2} \mathrm{O}$-graphene nanocomposites and their highly efficient photocatalytic performance for dye pollutants, RSC Adv., 7 (47), 29284-29294.
[18] Yahya, N., Aziz, F., Jamaludin, N.A., Mutalib, M.A., Ismail, A.F., Salleh, W.N.W., Jafar, J., Yusof, N., and Ludin, N.A., 2018, A review of integrated photocatalyst adsorbents for wastewater treatment, J. Environ. Chem. Eng., 6 (6), 7411-7425.

[19] Anita, Yadav, A.K., Khatun, N., Kumar, N., Tseng, C.M., Biring, S., and Sen, S., 2017, Size and strain dependent anatase to rutile phase transition in $\mathrm{TiO}_{2}$ due to Si incorporation, J. Mater. Sci. - Mater. Electron., 28, 19017-19024.

[20] Hanaor, D.A.H., and Sorrell, C.C., 2011, Review of the anatase to rutile phase transformation, J. Mater. Sci., 46, 855-874.

[21] Rahmawati, F., Wahyuningsih, S., and Irianti, D., 2014, The photocatalytic activity of $\mathrm{SiO}_{2-}$ $\mathrm{TiO}_{2}$ /graphite and its composite with silver and silver oxide, Bull. Chem. React. Eng. Catal., 9 (1), 45-52.

[22] Scarpelli, F., Mastropietro, T.F., Poerio, T., and Godber, N., 2018, "Mesoporous $\mathrm{TiO}_{2}$ thin films: State of the art" in Titanium Dioxide - Material for a Sustainable Environment, Eds. Yang, D., IntechOpen, Rijeka, Croatia.

[23] Fajriati, I., Mudasir, and Wahyuni, E.T., 2014, Photocatalytic decolorization study of methyl orange by $\mathrm{TiO}_{2}$-chitosan nanocomposites, Indones. J. Chem., 14 (3), 209-218.

[24] Ikeda, M., Kusumoto, Y., Somekawa, S., Ngweniform, P., and Ahmmad, B., 2006, Effect of graphite silica on $\mathrm{TiO}_{2}$ photocatalysis in hydrogen production from water-methanol solution, $J$. Photochem. Photobiol., A, 184 (3), 306-312.

[25] Lang, J., and Matějka, V., 2013, Graphite/titanium dioxide composite, Proceedings of The $5^{\text {th }}$ International Conference NANOCON 2013, Brno, Czech Republic, 16-18 October 2013.

[26] Andriantsiferana, C., Mohamed, E.F., and Delmas, H., 2013, Photocatalytic degradation of an azo-dye on $\mathrm{TiO}_{2} /$ activated carbon composite material, Environ. Technol., 35 (1-4), 355-363.

[27] Guidetti, G., Pogna, E.A.A., Lombardi. L., Tomarchio, F., Polischuk, I., Joosten, R.R.M., Ianiro, A., Soavi. G., Sommerdijk, N.A.J.M., 
Friedrich, H., Pokroy, B., Ott, A.K., Goisis, M., Zerbetto, F., Falini, G., Calvaresi, M., Ferrari, A.C., Cerullo, G., and Montalti, M., 2019, Photocatalytic activity of exfoliated graphite- $\mathrm{TiO}_{2}$ nanoparticle composites, Nanoscale, 11 (41), 19301-19304.
[28] Salgado, B.C.B., and Valentini, A., 2019, Evaluation of the photocatalytic activity of $\mathrm{SiO}_{2} @ \mathrm{TiO}_{2}$ hybrid spheres in the degradation of methylene blue and hydroxylation of benzene: Kinetic and mechanistic study, Braz. J. Chem. Eng., 36 (4), 1501-1518. 